\title{
PEMBENTUKAN PAKET WISATA BERKELANJUTAN PADA KELOMPOK SADAR WISATA DESA BUKIT TINGGI KECAMATAN GUNUNGSARI
}

\author{
Sulhaini ${ }^{\left.{ }^{*}\right)}$, Rusdan $^{1}$, , Rahman Dayani ${ }^{1)}$ \\ 1)Fakultas Ekonomi dan Bisnis Universitas Mataram \\ Jalan Majapahit Nomor 62, Kota Mataram, Provinsi Nusa Tenggara Barat \\ *alamat Korespondensi : sulhaini@unram.ac.id
}

\begin{abstract}
ABSTRAK
Salah satu daya tarik wisata yang sedang tumbuh dan banyak tersebar di Indonesia adalah Desa (Kampung) Wisata yang perkembangannya cukup pesat dan menjadi perhatian banyak pihak. Perkembangan desa wisata memerlukan pendekatan yang melibatkan partisipasi aktif masyarakat lokal guna mendorong ekonomi produktif yang dilakukan oleh masyarakat sendiri. Namun, masih banyak kegiatan pariwisata di perdesaan cenderung mengeksploitasi sumber daya yang ada secara serampangan dan hanya mengejar jumlah kunjungan wisatawan dan akhirnya pengembangan desa wisata justru merusak sumber daya perdesaan terutama dalam jangka panjang. Oleh karena itu, tujuan kegiatan pengabdian kepada masyarakat ini adalah meningkatkan kreativitas Pokdarwis Desa Bukit Tinggi, meningkatkan wawasan kepariwisataan Pokdarwis Desa Bukit Tinggi, dan meningkatkan Jiwa Wirausaha Pokdarwis Desa Bukit Tinggi. Metode yang digunakan dalam kegiatan ini; pertama, melakukan diskusi kelompok terpusat (FGD), kedua, observasi lokasi ke seluruh obyek atau spot-spot wisata yang akan ditawarkan, ketiga, pendampingan penyusunan paket-paket wisata. Selanjutnya, penyuluhan kepariwisataan yang berkelanjutan dan manajemen bisnis pariwisata. Terakhir, pendampingan penerapan paket wisata yang telah dibuat selama dua bulan.
\end{abstract}

Kata kunci : Paket Wisata, Pokdarwis, Kecamatan Gunungsari

\section{PENDAHULUAN}

Pariwisata menjadi bagian tidak terpisahkan dari pembangunan suatu daerah dan terintegrasi dalam kerangka peningkatan kesejahteraan masyarakat baik lokal maupun nasional. Untuk itu, dibutuhkan adanya kemauan dan kesungguhan dari pemangku kebijakan pariwisata dengan meningkatkan wawasan dan pemahaman tentang aspek-aspek penting dalam kepariwisataan yang dapat memunculkan program pengembangan pariwisata yang lebih efektif dan berkelanjutan (Yoeti, 1994). 
Dalam rangka menghadapi paradigma baru dan tuntutan global, pembangunan pariwisata Indonesia hendaknya diarahkan untuk menganut standar kepedulian lingkungan yang tinggi dan kepedulian terhadap kepentingan ekonomi masyarakat lokal dan terhadap norma dan nilai budaya masyarakat (Soekardijo, 1997). Selain itu, pariwisata Indonesia harus mampu menyentuh kepentingan masyarakat miskin, sehingga memberikan daya ungkit yang kuat guna mengatasi permasalahan kemiskinan di Indonesia. Rahim (2012) menyatakan bahwa kegiatan pembangunan kepariwisataan pada hakikatnya harus melibatkan peran dari seluruh pemangku kepentingan yang ada dan terkait, yaitu; Pemerintah, Swasta, Masyarakat.

Salah satu daya tarik wisata yang sedang tumbuh dan banyak tersebar di Indonesia adalah Desa (Kampung) Wisata yang perkembangannya cukup pesat dan menjadi perhatian banyak pihak. Perkembangan ini tentunya harus disikapi dengan mengembangkannya, menatanya, dan mengelolanya dengan memperhatikan manfaat bagi masyarakat dan lingkungan sekitarnya. Salah satu pendekatan dalam pengembangan pariwisata yang melibatkan partisipasi aktif masyarakat lokal adalah pengembangan Desa Wisata yang sekaligus dapat menangkap peluang kecenderungan wisata yang saat ini mengarah kepada pariwisata dengan tujuan khusus. Dayani dan Sagir (2013) menyatakan bahwa Pulau Lombok memiliki banyak desa yang memproklamirkan diri sebagai Desa Wisata dengan menampilkan ciri khas masing-masing dan beberapa diantaranya telah terkenal hingga ke mancanegara, seperti: Sesaot dan Narmada (Lombok Barat); Kerujuk (Lombok Utara); Bilebante dan Setanggor (Lombok Tengah); Sembalun dan Tete Batu (Lombok Timur). Perkembangan Desa Wisata tersebut didasarkan pada peran serta seluruh masyarakat setempat dengan memanfatkan sumber daya alam, sumber daya manusia, serta sumber daya budaya yang tersedia. Untuk itu, perlu dilakukan pembangunan pariwisata lintas sektor dengan tujuan untuk mencapai perkembangan pariwisata yang berkelanjutan serta inklusif yang berdampak positif bagi lingkungan hidup dan budaya setempat.

Pengembangan Desa Wisata akan mendorong ekonomi produktif yang dilakukan oleh masyarakat sendiri. Selain itu, sektor pariwisata juga diyakini dapat meningkatkan kesejahteraan masyarakat lokal, sehingga secara tidak langsung dalam jangka panjang dapat menjamin keberlanjutan kegiatan kepariwisataan sebagai bagian dari pengembangan ekonomi lokal dan daerah baik untuk generasi masyarakat saat ini maupun 
masa yang akan datang. Selanjutnya sektor pariwisata juga dapat menjadi katalisator peningkatan keterkaitan kota-desa serta menstimulasi perkembangan desa dari desa miskin menjadi desa berkembang dan selanjutnya menjadi desa mandiri.

Ironisnya, masih banyak kegiatan pariwisata di perdesaan yang cenderung mengeksploitasi sumber daya yang ada secara serampangan. Tujuan membangun desa wisata kemudian bukan lagi untuk kesejahteraan masyarakat dan pelestarian lingkungan desa namun hanya untuk mengejar jumlah kunjungan wisatawan. Akibatnya banyak daya tarik wisata perdesaan yang rusak karena bentuk-bentuk wisata massal yang dilakukan, padahal ini akan merusak sumber daya perdesaan jangka panjang. Selama ini desa sebagai sebuah entitas kehidupan sering diperlakukan sebagai obyek pembangunan. Akibatnya banyak terjadi tumpang tindih kegiatan yang bukannya memperkuat namun justru melemahkan desa.

Desa Bukit Tinggi dengan topografi yang berbukit-bukit merupakan desa yang baru muncul dan mulai dikenal sebagai salah satu daerah tujuan wisata alam Gunungsari. Potensi wisata yang dimiliki Desa Bukit Tinggi relatif banyak terutama wisata yang memanfaatkan alam, seperti: hutan lindung, air terjun, dan lain-lain. Aktivitas pariwisata di Desa Bukit
Tinggi ini dikelola oleh Kelompok Sadar Wisata (Pokdarwis) yang masih belum banyak memiliki wawasan pariwisata. Mereka sangat menyadari kondisi pengetahuan tersebut dan sangat membutuhkan adanya sentuhan program peningkatan kapasitas anggota Pokdarwis tersebut dari pihak manapun yang peduli dengan pengembangan pariwisata berbasis masyarakat desa.

\section{Mereka sangat ingin} mengembangkan seluruh potensi wisata yang ada tersebut sebagai satu kesatuan (terintegrasi) dalam bentuk paket wisata dengan konten wisata yang bervariasi. Dengan demikian mereka ingin mendesain beberapa alternatif paket wisata baik yang dilakukan dengan berjalan kaki maupun bersepeda dengan tarif yang berbeda. Prinsip utama paket wisata yang disusun adalah pelibatan masyarakat sebagai pelaku utamanya, karena akan memberikan jaminan terlaksananya Pariwisata Berkelanjutan di Desa Bukit Tinggi tersebut yang memanfaatkan sumber daya lokal dan menjaga kelestarian lingkungan hidup dalam jangka panjang. Dengan prinsip ini tentunya akan mendatangkan manfaat ekonomi dan menjadikan lingkungan bersih yang pada akhirnya dapat langsung dirasakan oleh masyarakat Bukit Tinggi khususnya dan masyarakat yang lebih luas umumnya. 
Berdasarkan kenyataan tersebut dirasa sangat perlu dilakukan kegiatan pendampingan dalam pembentukan paket wisata dimaksud dan memberikan pelatihan manajemen dalam bisnis pariwisata berkelanjutan di Desa Bukit Tinggi Kecamatan Gunungsari dalam rangka meningkatkan kualitas implementasi pariwasata berkelanjutan di kawasan wisata berbasis masyarakat tersebut, sehingga tercapai optimalisasi pemanfaatan sumber daya lokal dan pelesatrian lingkungan. Adapun tujuan dari pelaksanaan kegiatan pengabdian masyarakat ini adalah: Meningkatkan kreativitas Pokdarwis Desa Bukit Tinggi, (b) Meningkatkan wawasan kepariwisataan Pokdarwis Desa Bukit Tinggi, (c) Meningkatkan Jiwa Wirausaha Pokdarwis Desa Bukit Tinggi.

\section{METODE PELAKSANAAN}

Metode pemecahan masalah yang digunakan dalam pengabdian ini adalah;

\section{(a) Diskusi kelompok terfokus ( FGD )}

Focus group discussion melibatkan pokdarwis di desa wisata Bukit Tinggi, yang merupakan metode yang digunakan untuk menggali potensi untuk pengembangan desa wisata. Dengan metode ini dapat pula digali berbagai kendala atau permasalahan serta solusi yang paling mungkin bisa dilakukan untuk pengembangan lebih lanjut.

\section{(b) Observasi}

Observasi dilakukan dengan melihat dan mencermati lokasi ke seluruh obyek atau spot-spot wisata yang akan ditawarkan secara terintegrasi yang dilakukan oleh Tim Pelaksana dan Pokdarwis Desa Bukit Tinggi. Observasi ini dilakukan bersama dengan Pokdarwis untuk identifikasi tracking yang terbaik dan lain lainyang akan menjadi produk unggulan desa

(c) Pendampingan penyusunan paket wisata

Pendampingan ini dimaksudkan untuk membantu pokdarwis dalam menyusun/mengembangan produk unggulan desa

(d) Penyuluhan

Penyuluhan ditujukan untuk meningkatkan keterampilan manajemen pariwisata berkelanjutan pokdarwis sehingga penyuluhan menekankan pada kepariwisataan yang berkelanjutan dan manajemen bisnis pariwisata, dengan materi: wawasan kepariwisataan berkelanjutan; kewirausahaan; dan Aspek pasar dan pemasaran dalam bisnis pariwisata,
(e) Pendampingan

Pendampingan selama dua bulan merupakan metode terakhir yang diterapkan dalam kegiatan pengabdian kepada masyarakat ini untuk memastikan dan menguatkan pengembangan desa wisata Bukit Tinggi. Dengan metode ini diharapkan pokdarwis mampu secara mandiri 
mengelola dan mengembangkan wisata di desanya secara berkelanjutan.

\section{HASIL DAN PEMBAHASAN}

1. Hasil dan pembahasan Fokus Group Discussion (FGD)

Pelaksanaan kegiatan

pengabdian kepada masyarakat ini diawali dengan kegiatan diskusi kelompok terfokus (FGD), kegiatan ini dilaksanakan bertempat di Masjid Desa Bukit Tinggi. Diskusi diikuti oleh 16 orang, tiga orang dari tim pengabdian Fakultas Ekonomi Dan Bisnis Universitas Mataram dan 13 orang pengurus pokdarwis Desa Bukit Tinggi Kecamatan Gunungsari Kabupaten Lombok Barat. Hasil FGD dapat diidentifikasi; (a) Permasalahan: pokdarwis Desa Bukit Tinggi belum memiliki paket wisata berkelanjutan dan belum menerapkan manajemen pariwisata berkelanjutan, (b) Terdapat banyak potensi yang belum diekploitasi, diantaranya ; hutan dan bukit-lembah (panorama alam).

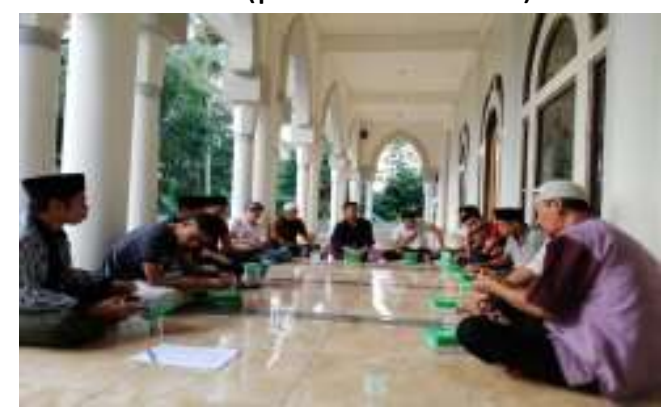

Gambar 1. Suasana Focus Group Discussion
2. Hasil dan pembahasan Observasi

Observasi lokasi dan yang diikuti oleh Tim Pelaksana pengabdian Unram dan pengurus inti Pokdarwis Desa Bukit Tinggi. Hasil observasi, teridentifikasi bahwa terdapat berbagai potensi yang dapat pertimbangan dalam menyusun paketpaket wisata sebagai berikut; hutan, bukit-lembah (panorama alam), air terjun, sungai, camping graound, rencana pembangunan bendungan bukit tinggi, penyadapan air nira manis, pengolahan (gula semut, gula merah, gula bricket, dan lainnya).

3. Hasil dan pembahasan pendampingan penyusunan paket wisata

Berdasarkan hasil FGD dan observasi potensi, tim pengabdian bersama pengurus inti pokdarwis Desa Bukit Tinggi menyusun paket-paket wisata pada bertempat di rumah salah seorang pengurus pokdarwis Desa Bukit Tinggi. Hasil penyusunan paketpaket wisata tersebut, sebagai berikut ; ( a ) Soft Trekking Package ( paket berjalan santai ), yang ditawarkan dengan ketentuan sebagai berikut; 2 4 pax dengan biaya IDR 110.000,- , / 5 - 10 pax dengan biaya IDR 100.000,- / 11 - UP pax dengan biaya IDR 90.000,/ INCLUDING ; Guiding, Entrance Fee, Lunch box, Fresh Coconut, Bottle mineral water, ( b ) Camping Ground ( bumi perkemahan ), yang merupakan paket kegiatan yang sifatnya kembali 
ke alam atau back to nature dengan sarat dan ketentuan yang berlaku, sebagai berikut : $2-4$ orang dengan biaya IDR 150.000,- / 5-10 orang dengan biaya IDR 140.000,- / 11 - UP orang dengan biaya IDR 130.000,- / Including; dinner, breakfast, tent camp, bottle mineral water, warm coffee, security officer fees, ( c ) Keterlibatan pengolahan gula semut dan gula bricket, paket kegiatan ini intinya mengenalkan proses pembuatan atau pengolahn gula merah kepada wisatawan yang pada umumnya mereka tidak tahu, dengan sarat ketentuan yang berlaku ; $2-4$ orang dengan biaya IDR 110.000,- / 5 - 10 orang dengan biaya IDR 100.000,/ 11 - UP orang dengan biaya IDR 90.000,- / = Including; Guiding, Entrance Fee, Lunch box, Fresh Coconut, Bottle mineral water, warm coffee.

4. Hasil dan Pembahasan kegiatan penyuluhan

Penyuluhan dilaksanakan setelah penyusunan bertempat di masjid Desa Bukit Tinggi. Penyuluhan ini dilaksanakan oleh oleh Tim pengabdian dan diikuti oleh anggota dan pengurus pokdarwis desa Bukit Tinggi Kecamatan Gunungsari. Materi penyuluhan yang disampaikan meliputi; wawasan kepariwisataan berkelanjutan; kewirausahaan; dan Aspek pasar dan pemasaran dalam bisnis pariwisata.

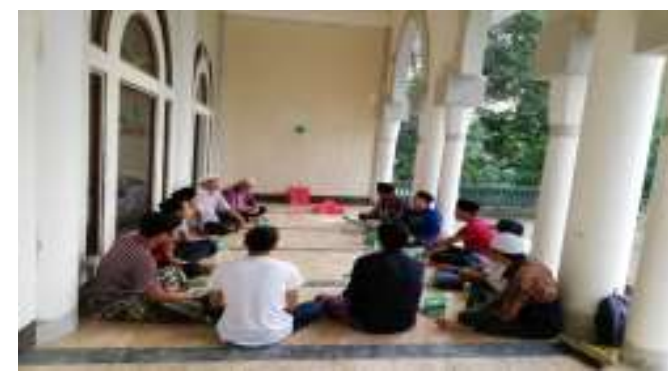

Gambar 2. Diskusi dengan warga desa

5. Hasil dan pembahasan kegiatan pendampingan

Pendampingan dilakukan selama dua bulan dan kegiatan ini dipandang perlu untuk memastikan kegiatan pengabdian pada masyarakat ini telah mampu menguatkan wisat desa Bukit Tinggi. Dengan pendampingan ini memungkinkan tim dapat menemukan potensi kendala ataupun potensi solusi serta potensi pengembangan lebih lanjut wisata desa Bukit Tinggi. Adapun tujuan akhir dari pendampingan adalah untuk menguatkan pengembangan desa wisata Bukit Tingg di mana pokdarwis mampu secara mandiri mengelola dan mengembangkan wisata di desanya secara berkelanjutan.

Adapun indikator keberhasilan kegiatan pengabdian masyarakat ini adalah sebagai berikut: (a) Keaktifan peserta saat pelatihan cukup tinggi terlihat dari suasana kegiatan diskusi dan tanya-jawab yang hidup terutama karena kehadiran tokoh-tokoh kunci pengurus Pokdarwis Desa Bukit Tinggi, (b) Peserta juga bersedia menularkan pengetahuannya kepada rekan-rekan Pokdarwis yang kebetulan tidak dapat 
menghadiri kegiatan pelatihan, (c) Terdatanya berbagai potensi pariwisata di Desa Bukit Tinggi, (d) Terbentuknya beberapa paket-paket wisata di Desa Bukit Tinggi, (e) Terbatasnya sarana jalan raya menuju lokasi wisata

\section{KESIMPULAN DAN SARAN}

\section{Kesimpulan}

Kesimpulan dari kegiatan pengabdian kepada masyarakat ini adalah:

1. Terjadinya peningkatan kreativitas Pokdarwis Desa Bukit Tinggi

2. Terjadinya peningkatan wawasan kepariwisataan Pokdarwis Desa Bukit Tinggi

3. Terjadinya peningkatan jiwa wirausaha Pokdarwis desa Bukit Tinggi

\section{Saran}

Saran-saran yang perlu diperhatikan:

1. Menindaklanjuti atau menerapkan paket-paket wisata yang sudah dibuat, dengan cara menawarkan paket-paket wisata tersebut baik melalui media sosial, iklan, ataupun media promosi lainnya,

2. Menerapkan konsep pariwisata berkelanjutan dengan cara melibatkan semua unsur Stakeholders, agar tercapai pemanfaatan sumber daya pariwisata secara optimal,

3. Selalu menjalin kerjasama dengan berbagai pihak seperti; Instansi pemrintah yang berkaitan dengan industri, UMKM, koperasi, pariwisata, dan kehutanan, LSM yang bergerak dibidang Lingkungan Hidup, kepolisian untuk dukungan keamanan, dan lain-lain,

4. Mengusulkan ke pemerintah kabupaten Lombok Barat atau instansi terkait untuk membuka atau pengerasan jalan menuju lokasi wisata,

\section{DAFTAR PUSTAKA}

Dayani D, Sagir J. 2013. Daya Saing Obyek Wisata Nusa Tenggara Barat, Studi pada Obyek Wisata Pulau Lombok. Laporan Penelitian BPPD NTB dan FEB Unram. Universitas Mataram : Mataram.

Rahim F. 2012. Pedoman Kelompok Sadar Wisata. Direktur Jenderal Pengembangan Destinasi Pariwisata Kementrian Pariwisata dan Ekonomi Kreatif : Jakarta.

Soekardijo RG. 1997. Anatomi Pariwisata (memahami Pariwisata Sebagai "systemic Lingkage). Gramedia Pustaka Utama : Jakarta.

Yoeti OA. 1994. Pengantar Ilmu Pariwisata. Angkasa : Bandung. 